\title{
The Notion of Woman as Symbol of Fidelity per Treatises of Fariduddin Attar
}

\author{
Gulchekhra Valeriyevna Izbullayeva \\ The Bukhara State University, Bukhara, Uzbekistan \\ Email: Izbullayeva@mail.ru
}

How to cite this paper: Izbullayeva, G. V. (2021). The Notion of Woman as Symbol of Fidelity per Treatises of Fariduddin Attar. Open Journal of Social Sciences, 9, 224-234. https://doi.org/10.4236/jss.2021.92015

Received: November 2, 2020

Accepted: February 16, 2021

Published: February 19, 2021

Copyright (c) 2021 by author(s) and Scientific Research Publishing Inc. This work is licensed under the Creative Commons Attribution International License (CC BY 4.0).

http://creativecommons.org/licenses/by/4.0/ (cc) (i) Open Access

\begin{abstract}
In the following article the fidelity of woman, daughter-in-law is expressed in the treatises of Fariduddin Attar: such as the leader, rational woman, tolerance, iman, purity and courage are reconsidered. The scholar substantiates the meaning of the contradictory views in the description of the symbolics of woman. The woman reaches the superior levels based on attention, esteem, training and respect, otherwise she leads many people to the ignorance. It is indicated that the fidelity is the best spiritual-ethical characteristics of human. The woman expressing the peculiarities such as iman, faith, gratitude, patience and firmness based on her fidelity can be sample for every person. The abstract focuses on the issues of fidelity of woman. The research is based on the comparative study of diverse sources. The aim of the study is to reveal the issues of fidelity in the early Islamic period.
\end{abstract}

\section{Keywords}

Sufi Woman, Open-Mindedness, Dignity, Fidelity, Assistance, Humbleness, Patience, Good Deeds

\section{Introduction}

Today, a wide spectrum of works are being carried out in Uzbekistan on the increasing the socio-political and social activity of women, creating conditions for them to realize their abilities and potential in various fields and sectors, ensuring unconditional observance of their rights and legitimate interests, comprehensive support for motherhood and childhood, as well as, extensive work is being done to strengthen the institution of the family.

In accordance with the Decree of the President of the Republic of Uzbekistan Shavkat Mirziyoyev "On measures to radically improve the activities in the field of support of women and strengthening the institution of the family" (PF-5325, 
2018), series of measures on the strengthening and improving the role of women in the spiritual and moral environment in families of Uzbekistan, conferences at the national and international levels are organized, based on the principle of indifference to the problems of every woman in society. The works of thinkers such as A. Navai, M. Iste'lami, scientists such as N. Komilov Sh. Babakhanov, M. Kenjabekov, M. U. Khudjova, A. Shimmel and others are reconsidered.

\subsection{The Actuality of the Research}

If we look at the history of the Uzbek people, caring for and respecting women have always been at the forefront. In folk epics, the Avesto, the Qur'an, the hadiths, and the masterpieces of our thinkers, the image of the feminine is glorified and idolized. For example, there are a number of hadiths that glorify women, such as "Paradise is under the feet of mothers" (Babakhanov, 1990) or "Those who are kind to their wives are the best among you" (Babakhanov, 1990).

\subsection{Literature Review}

At the same time, the thinker Farididdin Attar in his works glorifies the image of a woman and describes her way of life as an example of devotion. Farididdin Attar, whose real name was Muhammad Abu Bakribn Ibrahim, lived and worked in Nishapur from about $1148 / 51$ to $1219 / 21$. The Sufi poet is also recognized for his promotion of Sufism in his works. Fariduddin Attar is the author of the following books: "Bulbulnama", "Mantiqut-tayr", "Ilahinama", "Ushturnama”, “Javhar-uz-zat”, “Haylaj”, “Asrarnama”, "Sharh-ul-qalb”, “Musibatnama”, “Pandnama”, “Devan”, “Tazkiratul-awliya” (Saidov, 2013).

Sh. Babakhanov, M. Kenjabekov, M. U. Khudjova, A. Shimmel, M. Iste’lomiy, N. Komilov, Arberry A. J., Kh. Khomidi (Arberry, 1958; Iste'lomi, 2001; Komilov, 2009; Khomidi, 2009; Navoi, 2001) have deep insights regarding the issues of women in medieval context having impact on the contemporary trends.

\subsection{Materials and Method}

The data for this study was obtained from manuscripts and gathered resources from library. The use of manuscripts is common in the study of history pedagogy. 13 sources were used to complete the clarify thesis. Comparative resources have been found in similar primary data collection studies. Hence, the exclusion from further analysis is conducted.

\subsection{The Degree of Studiedness of the Problem}

In the content of Farididdin Attar's works, the image of an old woman (momo), mother, daughter, woman, bride, who has a high place in society, is very well described. In the works of the thinker, especially in the early days of Sufi women, their more active participation in social life and their significant role in society are shown. In the image of Sufi women, that is, women who have a place in society in terms of social, spiritual, enlightenment: Eve, Mary, Anbar ana, Bibi- 
mushkulkushad, BibiSeshanba, Aisha, Fatima, Robia al-Adawiya and others.

Women who were known in society as a symbol of devotion and saints and who recognized themselves were called "Sayyida" (Khusniddinov, 2004). For example, Eve, or "Evve" in ancient Hebrew, is the source of life, the wife of Adam, the first woman, and the mother of the human race, Mother Anbar was the patron saint and pir of women in folklore and Islamic traditions, Bibimushkulkushad is a woman who makes things easy, BibiSeshanba is the guardian of family happiness, Mary is a pious, sincere woman, Aisha, The wife of Muhammad (peace and blessings of Allaah be upon him), the daughter of the first Caliph Abu Bakr, Fatima is the youngest daughter of Muhammad (peace and blessings of Allah be upon him).

\section{Main part}

\subsection{Social Conditions Formed Ideas}

In the works of Fariduddin Attar, special attention is paid to the personality of Rabia al-Adawiya. His image is characterized by the involvement of society in all socio-spiritual relations, in the context of devotion he is embodied as a symbol of progress, wisdom, perseverance, faith, purity, courage.

\subsection{Rabia al-Adawiya}

Rabia al-Adawiya (Khusniddinov, 2004) (713/714-801) was a well-known representative of the Basra ascetics. She was sold as a slave in her childhood. She was later released because of her piety and devotion to the ascetic lifestyle. She lived alone in the desert for several years. Rabia al-Adawiya was a supporter of rejecting everything except loving Allah. She was the first of the ascetics to emphasize that absolute love for Allah, without any benefit from Allah, is the essence of human spiritual life. Her ideas spread among the next generation of Sufis and formed the basis of the teachings of Bistami, Hallaj, IbnFarid, IbnArabi and other Sufis.

Fariduddin Attar, describing the image of Rabia, says in the story "Hazrat Abu Bakr and Hazrat Ali's devotion to the Prophet" (Nishapuri, 2012), "be the man of the Truth like Rabia" (Nishapuri, 2012), he mentions. Hence, the image of Rabia is distinguished in society by the fact that it is worthy of a high degree of self-education, advice and example even to men. The thinker enumerates Rabia's qualities and describes her as "not a woman, but a hundred and one men" (Nishapuri, 2012). Although Rabia was physically weak, fragile, and in need of protection, the strength of a hundred men in faith, patience, and perseverance is embodied in her. In addition, the image of Robia in the story is glorified as "the same pain with the whole body" (Nishapuri, 2012), "The light of the truth" (Nishapuri, 2012), "pure and spotless" (Nishapuri, 2012), The Companions of the Prophet (Nishapuri, 2012). In this regard, he said to be like Robia:

You are a handful of soil, know your word as soil, Know everyone pure, be pure (Nishapuri, 2012). 
Rabia was a Sufi woman who encourages the world to give up all its pleasures, to live the worldly life with true love, that is, the love of Allah. She is a person who understands the truth, who is able to glorify humanity as a humble person, who can count everyone as pure, and who can inspire them to purity. In history, the opposite of Robia's essence is the image of "sajoh" (Khusniddinov, 2004), that is, the image of a false prophetess.

Fariduddin Attar condemns the deception and deceit in women in society:

What is the world, if the woman is old, it leads fatality to several hundreds

of thousands (Nishapuri, 2012).

Hence, the thinker compares the two qualities embodied in the image of a woman in social life, showing that if the spiritual fortitude of one is more than a hundred men, the trick of the other in the way of material needs will destroy hundreds of thousands of men. At the same time, Farududdin Attar pointed out one of the weak qualities in the image of a woman and said:

Do not reveal your secrets to women, Then your secrets are spread everywhere (Nishapuri, 2012).

In the "Pandnama", entitled "Four things are not eternal" (Nishapuri, 2012), it is stated that four things in the world are not eternal, one of them being women's love, sincerity, respect is not eternal, and their conversation is also harmful. From the content of the contradictory views of the thinker in the depiction of the female image, we can understand that this image attains a high status if it is developed on the basis of attention, respect, upbringing, appreciation. In Farududdin Attar's treatises, the image of Rabia can be seen in a number of his other stories. For example, in the context of cultivating lust, renunciation of the world, and the symbol of love. In particular, "Rabia's spinning and selling" (Nishapuri, 2012), "HasanBasri and Rabia" (Nishapuri, 2012), "Love of Rabia and Bektash" (Nishapuri, 2012) are described.

According to the story, "Rabia walked for seven years to Mecca" (Nishapuri, 2012), Rabia walked the Kaaba for seven years. Now, as she approached Mecca and was about to perform the Hajj, her feminine apology was revealed. When he returned, he said, "O Zuljalal, I have suffered for seven years. When you finally reached my goal, you threw a thorn in front of me" (Nishapuri, 2012). The author mentions:

Until you fall in love, just like Robia, The basis of the event will not be revealed... (Nishapuri, 2012)

This incident refers to people who, for one reason or another, doubt their love for Allah. To understand the truth is to understand the essence of Hajj and not to perform it. Fariduddin Attar's story "Rabia” in "Ilahinama” (Nishapuri, 2012) describes Rabia's poverty, inattention to worldly pleasures, and endurance in the face of trials. Rabia had a status (Nishapuri, 2012), (Schimmel, 1999) that is, she fasted, and for several days she did not eat salt. Her work was only in recovery, 
prayer, supplication, recitation. After a week of starvation, she was exhausted, and he finally shivered. Robia had a gentle neighbor, sometimes carrying a bowl of food. The poor Robia lay sick, and when she got up in the morning for iftar, she slowly turned on the light and saw that the cat had come and finished the meal. She went to the jug and said I would break my fast with water. She took the water and returned to the trail, tried to break her fast in the dark house when the candle went out, and suddenly the jug fell out of her hand and broke. The sorrow of the world is temporary, and the sorrow of the hereafter (return to the original) is based on eternity. This content is also reflected in the story "Rabia's Prayer to Almighty" (Nishapuri, 2012). A person who is pure, self-aware, and an idol of faith completely gives up from them. Whoever is caught between two worlds, or who has looked at the world, is described as a disbeliever.

The image of the Sufi woman is described by the author as a two-sided essence. On the one hand, their attractive appearance, and on the other hand, the rich inner world that complements each other represents an important inner magic of the scientist's work (Khudjova, 2006). Rabia was prominent as a symbol of reflecting the expression of essence, self and essence by her rapid answer to questions. In another story, the author reveals the essence of understanding the Truth through the image of Rabia. An ignorant person would call on the Truth (Nishapuri, 2012) and say: O Allah, open your door. As Rabia hears this, she replies: Tell me, man, when was this door closed? This door is always open, you just go and ask for it ...

In Fariduddin Attar's works, the image of a poor, old woman "momo" is embodied in the stories such as "An old woman asking for blessings from Sheikh Mihnai" (Nishapuri, 2012), "The Falcon and the Old Woman" (Nishapuri, 2012), "On somebody who asked about the stories of the elderwoman" (Nishapuri, 2012), "The story of Sultan Mahmud and the old woman" (Nishapuri, 2012), "The story of a heartbroken old woman" (Nishapuri, 2012). Through the image of an old woman, the author depicts a woman whose devotion, piety, and faith are stronger than all obstacles and even the most powerful kings on earth. In the story narrated by Faruddin Attar entitled "The wife of the Prophet" (Nishapuri, 2012) a description of women, a problem caused by a trait such as measuring the amount of attention, and how the Prophet (peace and blessings of Allah be upon him) found a solution to this problem. According to the story, one day the women gathered and asked the Messenger: Hey the chairman of world, who do you love more, who is more pleasing to your heart? If we knew, we would all be happy ... The Prophet (peace and blessings of Allaah be upon him) said: O my companions, be patient until today. I'll give you all an answer tomorrow ... The next day, late in the evening, the darkness fell, he called each woman separately and gave her a ring to hide, not a ring, but an ointment. Then he said, "Keep the ring, my dear, but keep it a secret, and don't tell anyone", and warned everyone not to reveal the truth. The night passed, the day became clear, the enlightened, women came to the prophet. They asked questions and waited 
silently for answers, the prophet began his speech, if I secretly gave a ring to someone, that person is the most beloved person to me ... The Women who heard this word, each one secretly rejoiced. They looked at each other, but someone did not know the secret ... Everyone said a secret in their hearts, but the secret was different with Aisha ...

Although the images of the wives of the great prophet are not described in detail in the "Ilahinama" (Khudjova, 2006), Attar still describes them as pure, immaculate, self-aware, and inspired by them, as the children of the caliph in the path of truth as an example, a means of education, and among the wives of the great Prophet, Aisha was shown as an example of balance, humility, purity, devotion and piety, especially for each of them. It is clear from this that our mother Aisha always supported our Prophet in faithfulness and served him as a companion in the path he took.

\subsection{Aisha of the First Caliph}

Aisha (May Allah be pleased with her) (613-678) (Khusniddinov, 2004): The wives of Muhammad (May peace and blessings of Allah be upon him) were the daughters of the first caliph, Abu Bakr. In the history of Islam, Aisha had a very high scientific position. Aisha (May Allah be pleased with her) is considered the narrator of many hadiths because of the fact that they lived directly with $\mathrm{Mu}$ hammad (May peace and blessings of Allah be upon him).The Companions would ask Aisha about some difficult issues in family relations. She also issued fatwas during the time of Abu Bakr, Umar and Usman. Aisha was well versed in tafsir, hadith, jurisprudence, and was well versed in Arabic language and literature. It is narrated that Aisha was a very humble woman who wore only a pair of shoes and a few shirts throughout her entire life.

\subsection{The Youngest Daughter of the Prophet}

The Prophet Muhammad (peace and blessings of Allah be upon him) was always a symbol of humility and urged those around him not to pay attention to the means of the world. Attar narrates the story of his daughter Bibi Fatima in the Ilahinama, "About Fatima's treasure" (Nishapuri, 2012). The image of Fatima is embodied as a symbol of family values, child loyalty, apparently humility, modesty, inwardly broad-mindedness, honor, patience. When our prophet was marrying the Fatima to Hazrat Ali: "Hey Osama call may daughter Zuhra". He said, my daughter, bring everything you have here. You're the light of my eyes, my plain road, I am sending you to Haydar, may soul ... The daughter agreed to the order, brought pillow. She brough carpet, miswak and new shoes. Brought one bowl, one pillow made of sheepskin. Afterwards she brought one more foulard with seven patchworks, combined everything.

The youngest daughter of Prophet, Fatima (ca. 605/606-632/633), was nicknamed Zahra (as a Rose) because of her beauty. Indeed, there are many legends about Bibi Fatima, especially the fact that Fatima, as the "queen of man" (Khus- 
niddinov, 2004), lived in extreme poverty, stirring up the imaginary world of Muslims. Because a girl has no greater and more precious dowry than morality and honor.

In the book "Dowry of Fatima" (Jihaznamai Fatima) (Schimmel, 1999) which is widespread in the Islamic world, the girl's dowry includes three blankets made by HazratAsma, a rug, a pillow filled with persimmon fronds, two hand mills, a bucket, a ceramic jug, a copper hum, a sieve, a towel, an unbleached leather, two shirts made of patchwork, one sock, one chair made of persimmon ... This was the dowry of Fatima, the daughter of the Prophet (peace and blessings of Allah be upon him). Fatima's real dowry was her faith and deeds. Although the poor little things that her father could give Fatima, even though her children were hungry, she shared her bread with the poor until the last ounce, and her children lacked clothes, all of this was interpreted in new tones each time, resulting in Fatima's image for Muslims turned into a bright symbol.

\section{Discussion}

In Fariduddin Attar's views, female devotion comes first and is described in a number of stories in different contexts. In one story, a woman came to Ali and handed him a golden pages. The sheikh said, "I have made a covenant that I will not take anything from Allah" (Nishapuri, 2012). And the woman said to him, O Ali, where did this happen to you? Look through the eyes of a brave man, there is nostranger. Here you havent't seen the agreement of the man, but the stranger. This story depicts the image of an enlightened woman who understands the essence of the Truth in her heart. Ali, on the other hand, is apparently portrayed as a doer of the Truth. The story points to an understanding of the essence of God from the inside out, not the outside through the image of the woman. Loyalty is synonymous with faithfulness, friendship, solidarity, sincerity. It is the most noble spiritual and moral quality of man. In Fariduddin Attar's story "As long as there is a Allah, I am not alone ... (Nishapuri, 2012)”, there was a woman who was pure. Her husband went on a trip, leaving her alone. Someone said that your life is spent in solitude, so how is your life? The woman said no, I'm not alone. As long as there is a Allah, My Allah always gives me a loaf of bread

Or you, you will say husband is your present, Do you have iyman, faith (Nishapuri, 2012)?

This story describes not only the woman's devotion to her family, her humanity, but also that she did not violate her honor for a loaf of bread. Qualities such as faith, belief, gratitude, patience, and perseverance in a woman have been shown to be an example to any man. In fact, in our society, a woman is the dignity of every family, a person in need of protection.

In the story "The Loyalty of a Pure Woman" (Nishapuri, 2012), the author describes the suffering of a woman in order to preserve her honor and in this case it is about people who betray their trust by misunderstanding a woman's need for protection. According to the story, there is a woman who has no equal 
in the beauty of her. Her husband set out for Hajj. The woman's husband had an ignorant brother, and the brother handed him over to his wife, telling him to keep in touch until he returned from the trip. His brother promised to take care of his brother's wife. He looked at some time and answered what she needed. $\mathrm{He}$ fell in love with his sister-in-law, lost his mind and told his feeling to sister-in-law. Sister in law said: Shame on you, if this is your opinion, where is your honor and respect for your brother? Is this your religion? Are you betraying the trust? Be merciful, God forgives you, give up these corrupt thoughts ...

After sister-in-law denies her brother-in-law's love, he slandered Madonna, took her to a judge, publicly humiliated sister-in-law, and draged sister-in-law into the desert with a stone storm. The woman's body was covered in blood in the desert. An Arab was riding his camel across the desert, and when he heard the woman's moan, he was saddened and helped her. The Arab was also fascinated by the woman's beauty and said, "Be my wife". Woman said: I have a husband as per sharia, how can I be someone else's partner? Seeing that the woman was a pure pearl, the Arab bowed his head and repented. There was a black slave in this Arab who suddenly fell in love with a moon-faced woman when he entered the house. When the intention of the slave towards the woman also did not come true, he slandered the Arab over the woman. Realizing the evil intentions of the Arab slave, he drove the woman away from her country by giving her a dirham for travel expenses. On the way, the woman rescued a young man with a dirham in her hand. The young man also fell in love with her blessing and told the woman about it. The woman said to him: Oh, ungrateful one, I have saved you, is this a reward for me? When the young man did not see the result of his love, he called a trader and sold her as a slave. The woman said to the merchant, "O buyer, do not try to take me". She said I am a Free Woman, I have a Husband. Bozurgan, at the request of the merchant, bought the woman for a hundred dinars and dragged her into aboard.

Both the merchant and the ship's crew fell in love with the woman. When the woman heard this news, she cried out to Almighty: "Oh, wise man, save me from this mystery". At that moment the flames rose and the people of the ship burned to ashes. When the woman came to her senses, she was alone in a huge ship. She told the people on the beach, dressed in men's clothes, to meet the king.

The king received him and told him what had happened to the guest in the young man's clothes and take the goods from the ship, and give me a house on the shore to worship. The time came for the king to die, and he bequeathed the ascetic young man to be king in my place, to give orders and decrees. He bequeathed it to the people so that they would be at peace. He said that and died. The ministers, the people and the emirs went to the woman and told her the king's last will and testament. The woman told them the whole truth and refused the state. The voice of a brave woman spread all over the world that her prayer would be answered, the sick would be healed, the paralyzed would be healed, and she would be on her way. 
The woman's husband returned from Hajj and found his house destroyed, and his brother blind, sick, and helpless. His brother was paralyzed, his legs and arms were nailed to the bed. His brother asked him for his wife, and his brother told him that his wife had committed adultery with a soldier, and that many people had witnessed it. The judge sentenced him to be stoned. He said she died of stoning. When he heard this, he was sad. Seeing his brother's condition, the brother heard about the doctor woman and put his brother on a donkey and set off. They reached the Arab door at nightfall. The Arab invited them, and he had a servant, his eyes were blind, and he promised to take him with you to that doctor's wife, so that he could get rid of this trouble and recovered. They set out and finally reached a village. They entered a house that was the home of an ignorant young man. The young man was blind, and without arms or legs in bed. When the patient's mother also heard about the doctor, she took her son with them and set off. They took the three patients and arrived at the doctor's residence in the morning. In the morning, the woman went out on the porch, saw her husband in the distance, and worshiped him with joy.

The woman, wearing a mask, covered her face and went out to the guests. The woman looked at the patients and said that these people are sinners, that they can get rid of their pain if they confess their sins, and if they do not confess, they will suffer for the rest of their lives. Three sick men confessed their sins in a thousand afflictions. The woman blessed them, corrected them, and took them out, and told her husband not to go out alone, but to stay. Then she took off the mask from her face, cried out for her husband and fainted. When the woman regained consciousness, the man said, "You are very much like my wife. If she didn't die, I would just tell you (Nishapuri, 2012)". She said, "It is I, my Allah, who has blessed me and saved me from trouble (Nishapuri, 2012)”. Her husband fell down and prostrated himself and thanked God. His brother was also embarrassed. The woman made her husband king of the country and the Arab minister. She built a fortress of happiness in her homeland and spent the rest of her life in prayer. This story depicts a woman's devotion very impressively and politely, it is expressed that a woman has risen to a high position through her perseverance and courage. Every time a woman, a mother sweats for her family, the quality that is found in every brave man is manifested in them. For example, the author describes the power of women and says:

If the spider is minor animal than it, Takes the bread from the jaw of lion

(Nishapuri, 2012).

So, a woman's passion is so powerful that no resistance can affect her. That is why this courage must always serve high lofty purposes. A woman should always be a symbol of devotion.

In "Ilahinama" Fariduddin Attor's enlightened views depict the image of a woman not only in the image of enlightenment, courage, but also in the image of devotion to love. An example of this is the story of "Yusuf and Zulayha" (Khudjova, 2006), (Nishapuri, 2012), (Schimmel, 1999), which became a legend among 
the people. In this legend, Zulayho appeared in the image of a woman who was burning in the fire of love. She was willing to do anything to reach the vision of her lover Joseph, for she was in love with him with all her being. The story depicts that only a person who knows what devotion and self-sacrifice are in the path of love can find a sign in the secret of love.

The image of a woman by Attar is always expressed on the basis of the ideas of honoring, respecting a woman. He describes whether a woman sees good or bad as a result of a change in the quantity and quality around her. No woman can bear a bad name on her own, she says, and the symbol of goodness is always hidden in her heart. For example, in the story "On the good deeds of a bad wife" (Nishapuri, 2012), I said to the Prophet, "There was a woman, but she was not a believer". While the woman was walking in the desert, she came across a well and a dog walking around the well. The dog was thirsty, longing for a drink, he realized, and hung his tongue out of his mouth. The woman looked at the dog, took pity on him, made her handkerchief rope and her shoes jug. He took water from the well it and held it for the dog, so her mercy went to Allah. I saw he that night of Me'raj, his face was the moon, heaven was his destination ... The bad woman gave the dog water, and God found a reward in her deed. The author says at the end of the story:

If you can present a pleasure to the heart, The additional benefit for you is not one but two (Nishapuri, 2012).

Hence, it is said that the only good deed of a woman is that which causes her to be highly rewarded. In this way, the thinker emphasizes that a person should strive for good deeds and always do good deeds, no matter what aspect of life he is in.

\section{Results}

Based on the processed sources we can mention that Attar had studied the issues of gender, fidelity and loyalty long before the term gender itsef appeared in the $20^{\text {th }}$ century. Farididdin Attar's image of an old woman (momo), mother, daughter, woman, bride, which has a significance place in society is well described. In particular it was presented that Sufi women were more actively involved in social life in the early days and their significant role in society was shown. Particular attention is paid to the personality of Rabia al-Adawiya, the image of the woman is distinguished by the involvement of society in all socio-spiritual relations, which is embodied in the chapter on devotion as a symbol of progress, wisdom, perseverance, faith, purity, courage.

In the works of Farididdin Attar, the image of women who are socially active is also described. Through the image of an old woman, the author depicts a woman whose devotion, piety, and faith are stronger than all obstacles and even the most powerful kings on earth. In the works of the thinker, our mother Aisha is a symbol of fidelity and devotion, in the image of Fatima is embodied in the image of family values, child loyalty, apparently humility, humility, inner gene- 
rosity, honor, patience.

\section{Conclusion}

Fidelity and loyalty are one of the noblest spiritual and moral qualities of a person. A woman's devotion can be an sample to any man through such qualities as faith, belief, gratitude, patience, and perseverance. The woman's passion is so strong that no obstacle can resist her. Therefore, this courage should always serve the highest positive goals. The image of a woman by Fariduddin Attar is always expressed on the basis of the ideas of glorifying women, honoring them, respecting them. The thinker describes whether a woman's good or bad vision depends on a change in the quantity and quality around her. No woman can bear a bad name on her own, a symbol of goodness is always hidden in her heart. Therefore, a woman should be respected and valued. We should definitely follow the example of these samples.

\section{Conflicts of Interest}

The author declares no conflicts of interest regarding the publication of this paper.

\section{References}

Arberry, A. J. (1958). Classical Persion Literature. London.

Babakhanov, S. (1990). Memoirs of Contemporaries about Al-Bukhari. In I. I. al-Bukhari (Tran.), Al-adab al-mufrad (Masterpieces of Literature). Uzbekistan: Tashkent.

Iste'lomi, M. (2001). Ilohiy ishq kuychisi. “Masnaviy"ga muqaddima. (Mavlono Jaloliddin Muhammad Balkhiy). In J. Muhammadi (Tran.), Persian. Tehran.

Khomidi, K. (2009). Scholars of Sufism. Tashkent: Шарқ.

Khudjova, M. U. (2006). Images of Women in "Ilokhinama" and "Khusravnama" of Fariduddin Attar: Abstract dis. ... Candidate of Philological Sciences: 10.01.03/Khudjova Mavjuda Urakovna. Tajikistan: Dushanbe.

Khusniddinov, Z. (2004). ISLAM Encyclopedia. T.: National Encyclopedia of Uzbekistan.

Komilov, N. (2009). Tasavvuf. Tashkent: Movarounnahr-O'zbekiston.

Navoi, A. (2001). Nasayim ul-muhabbat. In Collection of Perfect Works. Volume XX 17. Uzbekistan: Tashkent.

Nishapuri, S. F. A. (2012). Epics "Mantiqut-tayr", “Asrornoma”, "Ilahinama”, "Pandnama”, "Bulbulnoma”, "Ushturnoma”. In J. Kamal (Tran.), Farsi. Tashkent: Tamaddun.

PF-5325 (2018). On Measures to Definitely Improve Women's Support and Strengthening the Family Institute. https://lex.uz/ru/docs/-3546742

Saidov, A. (2013). Studies of Attar. Treasures of Farididdin Attor's Thinking. Tashkent: Sharq.

Schimmel, A. (1999). The Image of Women in the Islamic World (Jonon mening jonimda). Tashkent: Sharq Publishing House. 